\title{
THE GENERAL SYNOD OF THE ANGLICAN CHURCH OF AUSTRALIA
}

\author{
GARTH BLAKE SC
}

The 13th General Synod of the Anglican Church of Australia was held in Fremantle, Western Australia between 2 and 8 October 2004.

The major issue before the General Synod was child protection and professional standards against the background of the Church's failure to deal adequately with child sexual abuse by clergy and church workers. A Safe Ministry Policy Statement, Safe Ministry Check (screening questionnaires for clergy and church workers) and Faithfulness in Service (a national code for personal behaviour and the practice of pastoral ministry by clergy and church workers) were adopted. Detailed resolutions dealing with various aspects of child protection including structures, recruitment, standards of behaviour, formation for pastoral ministry, safe ministry training, pastoral support for the abused, pastoral support and supervision for abusers, pastoral support for clergy, joint church action, government action and Anglican Communion action were passed.

Canons providing for the establishment of a national Professional Standards Commission, episcopal discipline and standards, the creation of a National Register of all clergy and certain church workers, as well as to facilitate the relinquishment of the exercise of, and the deposition from, Holy Orders, were passed. With the passing of these canons the revision of the Canons of 1603, which began in the 1960s, was completed by the General Synod.

A bill for a canon to permit the consecration of women to the episcopate narrowly failed to obtain the required two-thirds majority in the Houses of Laity and Clergy. This bill provided for alternative episcopal ministry for those opposed to ministry from a woman bishop.

There was a prolonged debate on three motions relating to sexuality and gender relationships. Resolutions were passed that the General Synod does not condone the liturgical blessing of same sex relationships and the ordination of people in open committed same sex relationships. Another resolution was passed that the General Synod welcomes the initiative of the Federal Parliament in clarifying that marriage at law is the union of a man and a woman to the exclusion of all others, voluntarily entered into for life. A motion seeking the affirmation of the 1998 Lambeth Conference resolution 1.10 on Human Sexuality was not reached.

A structured debate and discussion on lay presidency took place. The Archbishop of Sydney presented the affirmative case. A resolution was passed which, inter alia, urges any diocesan synod legislating on this issue 
to consider the theological and legal issues and the implication for the unity of the Church and its ecumenical partners and the Anglican Communion and states that the General Synod does not condone the practice of lay and diaconal administration/presidency at the eucharist in the Church.

The term of the office of the Primate was shortened to the conclusion of the next ordinary session of the General Synod which is likely to be held in 2007. A new Primate will be elected on the retirement of The Most Revd Peter Carnley AO, Archbishop of Perth, in May 2005. All Primates to date have had both diocesan and primatial responsibilities. The limited term of office of the Primate will enable consideration to be given to a suitable model for the primacy including a full-time Primate with no diocesan responsibilities.

A resolution was passed whereby the Church adopted the text of a covenant with the Lutheran Church of Australia, formally committed itself to enter into this covenant with the Lutheran Church and affirmed its willingness to work with the Lutheran Church in the process of developing a distinct episcopal office.

Consideration was given to the issues of mission and attendances. With most dioceses experiencing numerical decline the General Synod requested action from the Standing Committee and the Bishops' Conference, and urged each diocese to foster mission.

The first step to alter the Constitution relating to communion with other Churches took place with the passing of the Relations with Other Churches Canon 2004. At present the Church is in communion with the Church of England and with Churches in communion therewith so long as communion is consistent with the Fundamental Declarations in the Constitution. The amendment provides that the Church will continue in communion with the Church of England and that the General Synod may make canons (a) declaring those Churches with which the Church is in communion, or (b) specifying the conditions for entering into communion with other Churches, so long as communion is consistent with the Fundamental Declarations in the Constitution. This amendment will not come into force until adopted by three quarters of the 23 dioceses including all five metropolitan dioceses.

Further details of the proceedings of the General Synod can be obtained from the Anglican Church of Australia website online at:

http://www.anglican.org.au/gs2004.cfm 